\title{
Segmental migration of the hindbrain neural crest does not arise from its
} \section{segmental generation}

\author{
J. Sechrist ${ }^{1}$, G. N. Serbedzija ${ }^{2}$, T. Scherson ${ }^{1}$, S. E. Fraser ${ }^{2}$ and M. Bronner-Fraser ${ }^{1, \star}$ \\ ${ }^{1}$ Developmental Biology Center, University of California, Irvine, CA 92717, USA \\ 2Division of Biology, California Institute of Technology, Pasadena, CA, USA \\ *Author for correspondence
}

\section{SUMMARY}

The proposed pathways of chick cranial neural crest migration and their relationship to the rhombomeres of the hindbrain have been somewhat controversial, with differing results emerging from grafting and DiIlabelling analyses. To resolve this discrepancy, we have examined cranial neural crest migratory pathways using the combination of neurofilament immunocytochemistry, which recognizes early hindbrain neural crest cells, and labelling with the vital dye, DiI. Neurofilamentpositive cells with the appearance of premigratory and early-migrating neural crest cells were noted at all axial levels of the hindbrain. At slightly later stages, neural crest cell migration in this region appeared segmented, with no neural crest cells obvious in the mesenchyme lateral to rhombomere $3(\mathrm{r3})$ and between the neural tube and the otic vesicle lateral to $r 5$. Focal injections of

\section{INTRODUCTION}

The neural crest is a cell population unique to vertebrates and higher chordates, which leaves the dorsal neural tube to migrate extensively. Because neural crest cells intermix and interact with many tissues during their migratory phase, cell marking techniques must be used to follow their migration and differentiation. Grafting experiments, in which segments of the neural tube labelled with tritiated thymidine (Weston, 1963; Johnston, 1966; Noden, 1975) or the quail nuclear marker (LeDouarin, 1973; LeLievre and LeDouarin, 1975; Noden, 1978a,b; Couly and LeDouarin, 1990) are transplanted into unlabelled hosts, have been used to create a labelled population of neural crest cells that can be followed over time. Quail/chick chimerae have been particularly useful because the heterochromatin marker is stable through cell division, enabling long-term identification of the descendants of implanted cells. Recently, two methods have emerged which allow the neural crest to be followed without surgery. In the first, antibodies such as HNK-1 and NC-1 are used to recognize early-migrating neural crest cells (Vincent and Thiery, 1984; Tucker et al., 1984). In the second, the lipophilic vital dye, DiI (Honig and Hume, 1984) is used to label the neural tube or neural folds in a wide
DiI at the levels of $r 3$ and $r 5$ demonstrated that both of these rhombomeres generated neural crest cells. The segmental distribution of neural crest cells resulted from the DiI-labelled cells that originated in $r 3$ and r5 deviating rostrally or caudally and failing to enter the adjacent preotic mesoderm or otic vesicle region. The observation that neural crest cells originating from r3 and $r 5$ avoided specific neighboring domains raises the intriguing possibility that, as in the trunk, extrinsic factors play a major role in the axial patterning of the cranial neural crest and the neural crest-derived peripheral nervous system.

Key words: neurofilament proteins, DiI labelling, rhombomeres, segmentation, hindbrain variety of species, including mammals (Serbedzija et al., 1989, 1990).

Cell marking techniques have revealed that the neural crest is regionalized; cells derived from different axial levels follow distinct migratory pathways and give rise to a stereotyped set of derivatives. Based on these differences, the levels along the neural axis have been designated (in rostrocaudal order) as cranial, vagal, trunk and lumbosacral (LeDouarin, 1982). Cranial neural crest cells, which migrate to form a variety of neuronal and non-neuronal cell types, can be subdivided further into groups designated here as caudal forebrain, midbrain, rostral hindbrain and caudal hindbrain (which overlaps with rostral vagal) neural crest cells; each group has a somewhat different pattern of migration and prospective derivatives. For example, neural crest cells originating in the midbrain migrate primarily as a broad, unsegmented sheet of cells under the ectoderm; they contribute to derivatives ranging from the periocular skeleton, the connective tissue of the eye (including the sclera, choroid, cornea and iris), and the membrane bones (maxillary, prefrontal, nasal and temporal) of the face, to the ciliary ganglion, part of the trigeminal ganglion and Schwann cells (LeDouarin, 1982). In contrast, neural crest cell migration in the hindbrain appears to be segmented into 
three broad streams of cells, with no neural crest cells apparent at the level of rhombomere 3 (r3) or r5. Cells within the first stream populate the trigeminal ganglion and mandibular arch; those within the second populate the hyoid arch, as well as the geniculate and vestibular ganglia; those following the third stream populate the third and fourth branchial arches and peripheral ganglia (the superior, petrosal and nodose; Noden, 1975; D'Amico-Martel and Noden, 1983; Lumsden et al., 1991). Further caudally in the trunk region, neural crest cells migrate along two primary pathways: a ventral pathway, where sensory and sympathoadrenal precursor cells migrate in a segmental fashion through the rostral but not caudal half of each sclerotome (Rickmann et al., 1985) and a dorsal pathway, where presumptive pigment cells move underneath the ectoderm (Weston, 1963; Serbedzija et al., 1989).

In the trunk region, the segmental pattern of trunk neural crest cell migration through the sclerotome is imposed primarily by the mesoderm (Lewis et al., 1981; Keynes and Stern, 1984; Bronner-Fraser and Stern, 1991). In contrast, the mechanism of segmental migration in the hindbrain remains ill-defined. The pattern could arise from a segmentally restricted origin of neural crest cells within the neural tube or from a segmental migratory pattern imposed by the environment of the rhombencephalic neural crest. The DiIlabelling experiments of Lumsden and colleagues suggest that $\mathrm{r} 3$ and $\mathrm{r} 5$ do not form neural crest cells, consistent with the possibility that the segmental migratory pattern reflects a patterned origin within the neural tube (Lumsden et al., 1991).

It is important to resolve the origin and migratory routes of the hindbrain neural crest because the two possible scenarios described above imply widely different mechanisms of segmentation. To do so, we have performed a detailed evaluation of neural crest cell migration in the head using both antibodies and injections of the vital dye, DiI. Although it has been used widely to study trunk migratory pathways, the HNK-1 antibody is an inadequate marker for cranial neural crest cells because it fails to recognize some subpopulations. Surprisingly, an antibody against non-phosphorylated neurofilament proteins serves as a more reliable marker for premigratory and migrating hindbrain neural crest cells. Our results suggest that neural crest cells are generated by all rhombomeres in a rostral to caudal sequence. Thus, the absence of neural crest lateral to $r 3$ and r5 cannot be due solely to an absence of neural crest generation in $\mathrm{r} 3$ and $\mathrm{r} 5$. Rather, the metameric pattern may result from peripheral factors, such as interactions with the preotic mesoderm/ectoderm, with other crest cells or physical barriers such as the otic vesicle or first branchial groove.

\section{MATERIALS AND METHODS}

\section{Embryos}

White Leghorn chick embryos were incubated at $38^{\circ} \mathrm{C}$ until they reached the desired stages of development (4-28 somites; stages 816 of Hamburger and Hamilton, 1951). A window was cut in the egg, India Ink (Pelikan Fount) was injected under the blastoderm and the vitelline membrane was deflected from above the embryo. Embryonic age was determined by counting the number of somites in the embryo, as this offered a precise and simple method of staging. Throughout the text, embryonic stage is referred to according to the somite stage (ss) defined by the number of somites.

\section{Dil-labelling}

Whole neural tube injection

All injections were made by pressure with an $0.05 \%$ solution (weight/volume) of 1,1-dioctadecyl-3,3,3',3'-tetramethylindocarbo-cyanine perchlorate (DiI; Molecular Probes), made from an $0.5 \%$ stock solution in $100 \%$ ethanol diluted $1: 10$ in $0.3 \mathrm{M}$ sucrose. Prior to use, the DiI solution was heated to $37^{\circ} \mathrm{C}$ in order to prevent cold shock to the embryos and to help keep the DiI in solution. The injection micropipettes were back-filled with the DiI solution, attached to a picospritzer (General Valve) and inserted into the lumen of the neural tube using a micromanipulator (Marzhauser). Enough dye was expelled to fill much of the neural tube. After injection, the eggs were sealed with cellophane tape and returned to the incubator until the indicated times of fixation. Twenty embryos were injected at stages ranging from 4 to 18 ss and collected by the 11 to 28 ss.

\section{Focal injections}

Neural crest cells at specific cranial levels were labelled by inserting a micropipette into the dorsal aspect of the neural tube (using a micromanipulator; Marzhauser) and expelling a very small amount of the DiI solution. At the time of the injection, the injection site was visible through the dissecting microscope as a small red spot of dye in the tissue. For injections made at stages older than the appearance of rhombomere boundaries, the rhombomeres were used to guide the position of the micropipette and to judge the success of the injection. For injections made prior to the formation of rhombomere boundaries, small focal injections were made in the region we thought would give rise to a particular rhombomere, using the somites as landmarks. The fidelity of these injections was determined both at the time of the injection and at the time of analysis. At the time of fixation, the rostrocaudal extent of the dye-labelled cells within the neural tube was observed using an epifluorescence microscope. More than 120 embryos were injected at stages ranging from the 3 to 15 ss and collected at the 10 to 28 ss.

\section{Fixation and sectioning of embryos \\ Preparation for cryostat sections}

Embryos to be immunolabelled with neurofilament antibodies were fixed in $100 \%$ methanol overnight at $4^{\circ} \mathrm{C}$. To prepare for cryostat sectioning, they were washed in $0.1 \mathrm{M}$ phosphate-buffered saline (PBS, pH 7.4), placed sequentially in 5\% and $15 \%$ sucrose in PBS for 4 to 24 hours at $4^{\circ} \mathrm{C}$. Embryos were embedded in $15 \%$ sucrose and $7.5 \%$ gelatin (Sigma, 300 Bloom) for 4 hours at $37^{\circ} \mathrm{C}$, followed by embedding in fresh gelatin. After the gelatin set, the embryos were kept in the refrigerator for up to 1 week before cryostat sectioning. Immediately before sectioning, embryos were quickfrozen in liquid nitrogen and allowed to equilibrate to $-25^{\circ} \mathrm{C}$ prior to cutting transverse $10 \mu \mathrm{m}$ sections on a Zeiss Microm cryostat. Sections were mounted on subbed slides and stored at $-20^{\circ} \mathrm{C}$ until the time of staining. Embryos to be stained with the HNK-1 antibody were fixed in Zenker's fixative and cut at $10 \mu \mathrm{m}$ after embedding in paraplast.

DiI-labelled embryos were fixed from 3 to 24 hours in $4 \%$ paraformaldehyde/ $0.25 \%$ glutaraldehyde, washed in $0.1 \mathrm{M}$ phosphate buffer (PB) for 1 hour and soaked in a $15 \%$ sucrose solution for 8 to 12 hours at $4^{\circ} \mathrm{C}$. They then were embedded in gelatin as described above. Sections of DiI-labelled embryos were viewed without a coverslip shortly after sectioning. 

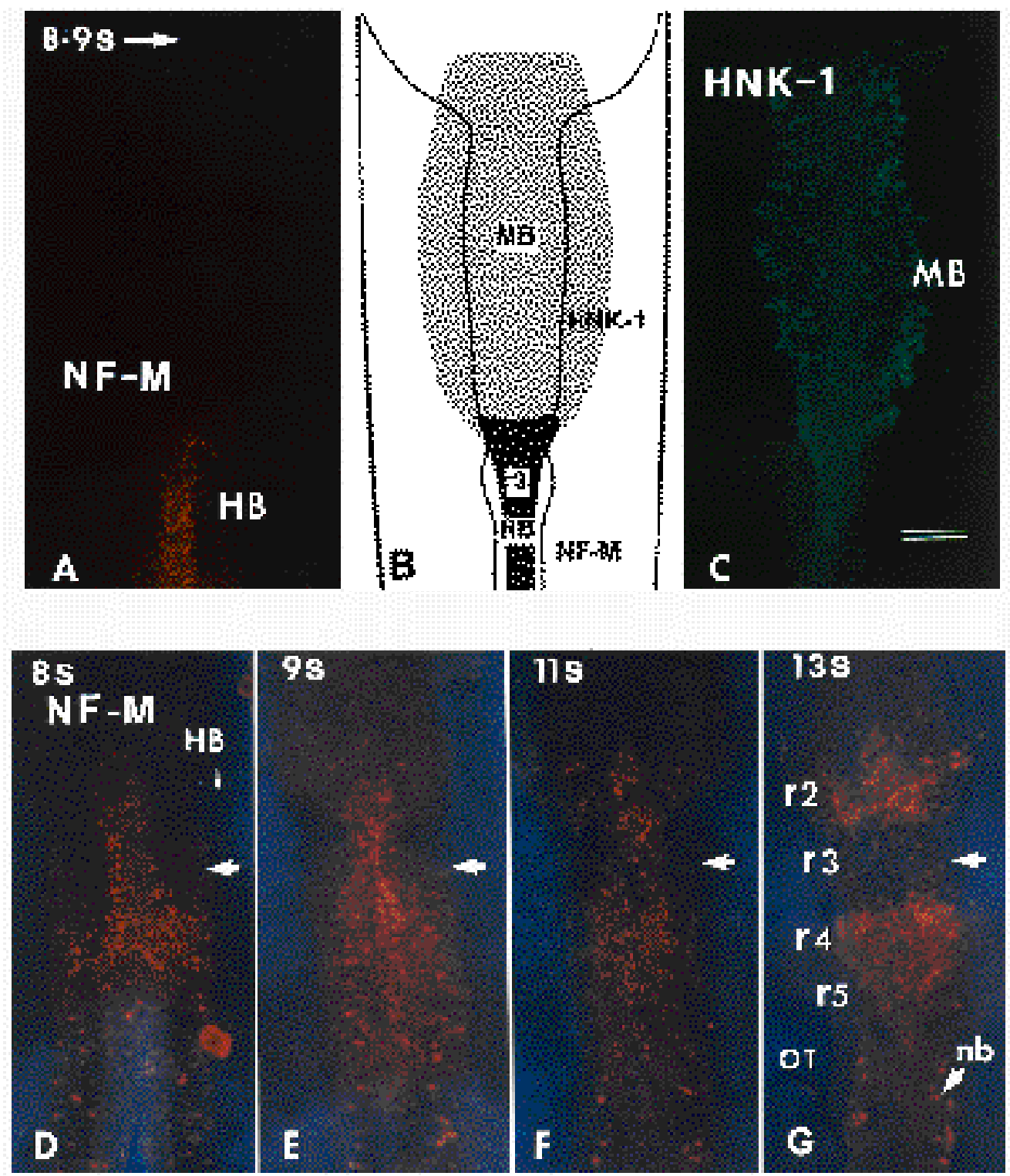

Fig. 1. Whole-mount immunoreactivity with NF-M (red) and HNK-1 (green) antibodies. (A,C) Patterns of NF-M and HNK-1 in the midbrain and rostral hindbrain of 8 ss and 9 ss embryos and (D-G) the changing pattern of NF-M immunoreactivity in the hindbrain of 8 to $13 \mathrm{ss}$ embryos. (A) At the 9 ss, NF$\mathrm{M}+$ cells (red) were seen in a continuous array over the dorsal midline of the hindbrain (HB) from $\mathrm{r} 2$ downward. (B) Schematic diagram illustrating the pattern of NF-M and HNK-1 immunoreactivity at the $8-9 \mathrm{ss}$; the sum of the two patterns represents that observed after whole neural tube labelling with DiI.

(C) HNK-1+ cells (green) were observed as a fan-like sheet expanding from the caudal forebrain, midbrain (MB) and rostral hindbrain; the only significant overlap between HNK-1 and NF-M reactivity was at the level of r2. (D-E) At the 8-9 ss, NF-M+ cells were distributed uniformly over the dorsal neural tube in the hindbrain, including $\mathrm{r} 3$ (arrow). (F) By the $11 \mathrm{ss,} \mathrm{some}$ $\mathrm{NF}-\mathrm{M}+$ cells have migrated from the neural tube and can be seen as a lateral stream adjacent to $\mathrm{r} 2$. At the level of r3 (arrow), fewer NF-M+ cells were observed than at previous stages, perhaps suggesting a reorganization of neural crest cells in this region. $(\mathrm{G})$ At the

13 ss, NF-M immunoreactivity was apparent at $\mathrm{r} 2, \mathrm{r} 4, \mathrm{r} 5$ and, to a lesser extent, $\mathrm{r} 6$ levels; at r6, vagal neural crest cell migration is conspicuous by the 16-18 ss. In contrast to the streams of NF-M+ neural crest cells evident adjacent to these rhombomeres, there were few if any NF-M+ cells in or adjacent to $\mathrm{r} 3$. The brightly NF-M reactive cells in the lateral neural tube caudal to r4 are reticular neuroblasts (nb; arrow). Bar, $120 \mu \mathrm{m}$ in A-C; $80 \mu \mathrm{m}$ in D-G.

\section{Immunocytochemistry}

\section{Antibodies}

A monoclonal antibody against the non-phosphorylated form of the intermediate molecular mass neurofilament protein (NF-M) was provided by Dr Virginia Lee (RMO 270.3; Lee et al., 1987). Hybridoma cells producing the HNK-1 antibody were obtained from American Type Culture. Both antibodies were applied to complete series of embryos prior to and during stages of neural crest migration (i.e. 6-17 ss).

\section{Staining of cryostat or paraplast sections}

Cryostat sections were warmed to $25^{\circ} \mathrm{C}$ prior to antibody staining. Paraplast sections were deparaffinized and rehydrated. Approximately $20 \mu \mathrm{l}$ of antibody solution, diluted 1:300 in PBS containing $0.1 \%$ BSA, for anti-NF-M and undiluted supernatant for HNK1 antibody, were applied to each section and incubated overnight in a humidified chamber either at $4^{\circ} \mathrm{C}$ or $25^{\circ} \mathrm{C}$. After incubation with primary antibodies, sections were washed in PBS for 5 minutes and incubated for 1-1.5 hours with FITC-conjugated antibodies against mouse IgGs (for anti-NF-M) or IgMs (for HNK-1). Sections were washed in PBS and coverslipped with gelmount (Biomeda). To ascertain the degree of non-specific staining by fluorescently conjugated secondary antibodies, the primary antibodies were omitted in some cases. No significant fluorescent signal was detectable with any of the secondary antibodies alone.

\section{Whole-mount staining}

Embryos were nutated in a detergent solution containing $0.1 \%$ Chaps, $0.1 \%$ Triton X-100 and 3\% BSA in 0.1 M PBS for 4 hours at $4^{\circ} \mathrm{C}$. Embryos then were washed three times in 0.1 M PBS for 1 hour at room temperature. The embryos to be stained with the HNK-1 antibody were immersed in a solution containing HNK-1 antibody supernatant, diluted $1: 1$ with staining solution $(0.1 \%$ 

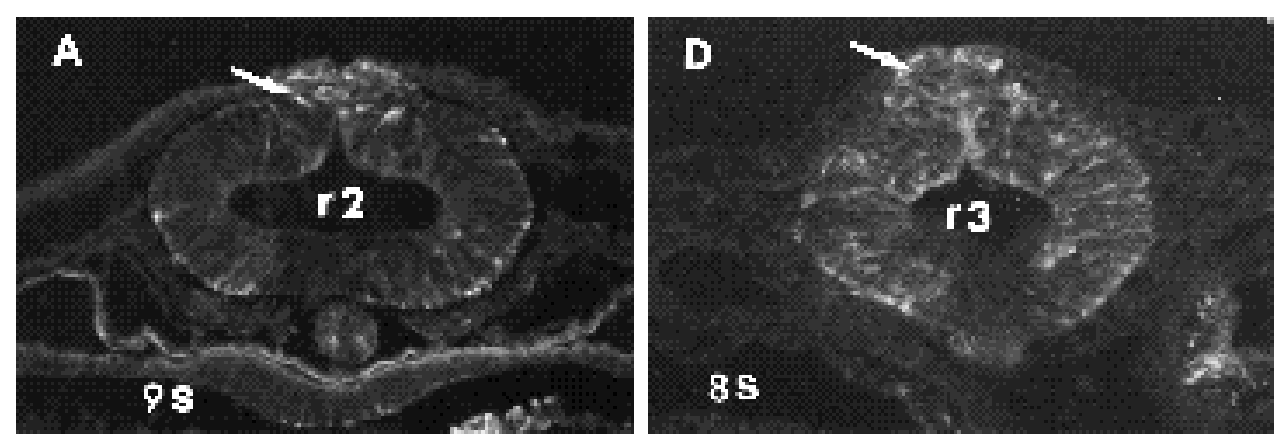

Fig. 2. NF-M (A-D) and HNK-1 (E-F) immunoreactivity in early hindbrain (HB) neural crest cells viewed in transverse section.
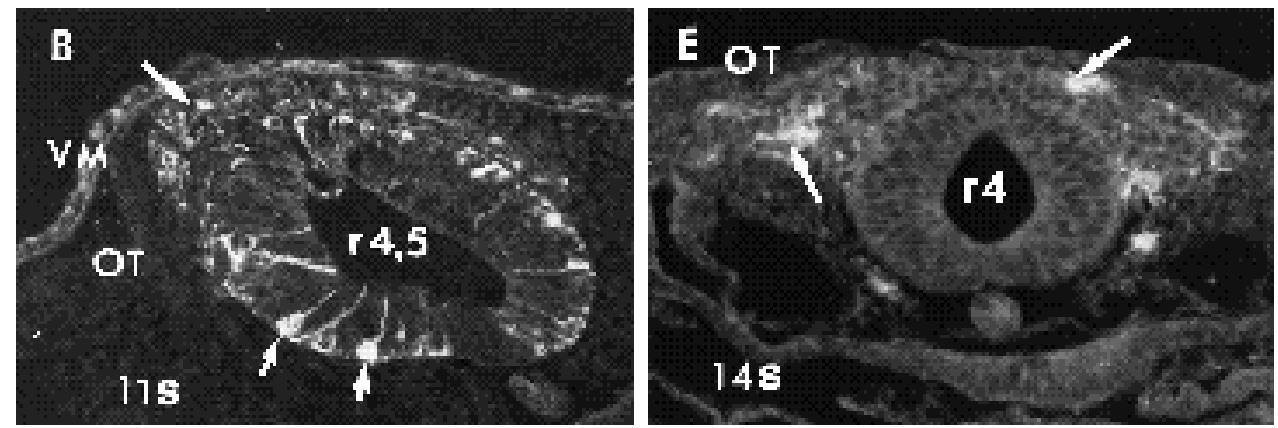

(A) At $r 2$ in a 9 ss embryo, NF$\mathrm{M}+$ cells (arrow) have initiated lateral migration along the dorsal portion of the neural tube. (B) At r4 and r5 levels, NF-M+ cells (arrow) accumulated between the otic vesicle (OT) and the dorsal hindbrain by the 10-11 ss; reticular neuroblasts (short arrows) in the hindbrain and cells of the vitelline membrane (VM) also were NF-M+. (C) At caudal
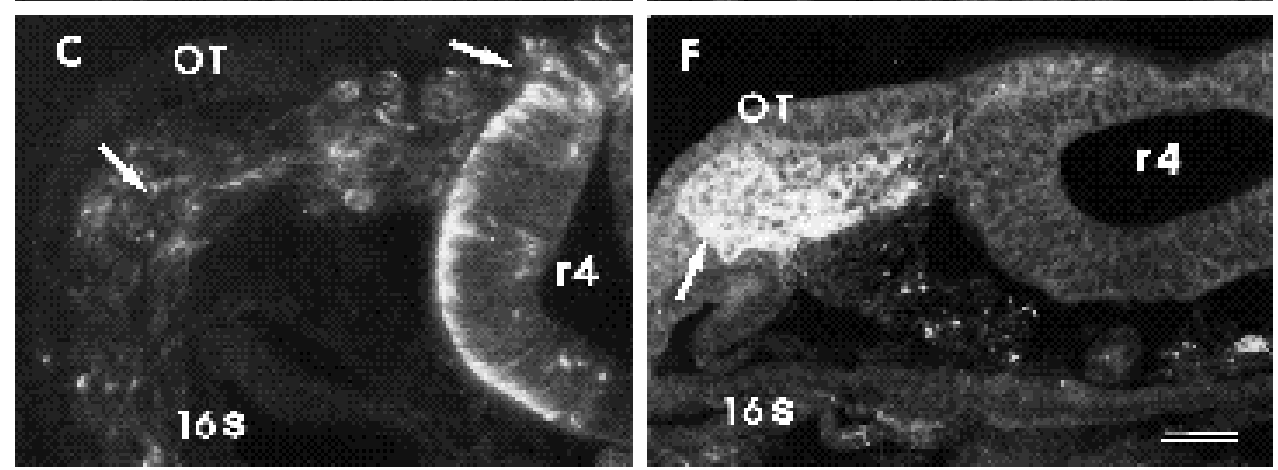
r3/rostral r4 level, numerous NF$\mathrm{M}+$ cells (arrows) have migrated laterally and ventrally beneath the otic placode/vesicle (OT) by the $16 \mathrm{ss}$; in the neural tube, a few $\mathrm{NF}-\mathrm{M}+$ reticular neuroblasts as well as transient NF-M staining of neuroepithelial cell basal processes was observed. Some NF-M+ cells were still seen in the dorsal midline of $\mathrm{r} 4$ at this stage. (D) In an 8 ss embryo at the level of $\mathrm{r} 3$, NF-M+ cells with the appearance of premigratory neural crest cells were observed in the dorsal midline, with some transient staining throughout the neural tube, except for the floor plate region. (E) In a section through $\mathrm{r} 4$ of a 14 ss embryo, only a few HNK-1+ cells were noted (arrows). (F) By the 16 ss stage, the HNK-1 immunoreactive cells (arrow) appeared similar in number and distribution to the NF-M immunoreactive cells. Bar, $34 \mu \mathrm{m}$.

Chaps, $0.1 \%$ Triton X-100 and $1 \%$ BSA in $0.1 \mathrm{M}$ PBS). The embryos to be stained for neurofilament were immersed in antibody diluted 1:300 in staining solution. The embryos were nutated at $4{ }^{\circ} \mathrm{C}$ for 8 hours, washed for 1 hour at room temperature and subsequently incubated in the appropriate secondary antibody diluted 1:300 (FITC-conjugated anti-mouse IgGs for neurofilament and FITC-conjugated anti-mouse IgMs for HNK-1 antibodies) in the staining solution. Embryos were washed three times in $0.1 \mathrm{M}$ PBS for 1 hour at room temperature and placed in well slides with PBS.

\section{Microscopy}

Whole-mounted DiI-labelled and antibody-stained embryos were viewed using a laser scanning confocal microscope (Biorad MRC 600 on a Zeiss Axiovert microscope). Slides were viewed with an Olympus Vanox Epifluorescence Microscope. A rhodamine filter set was used to visualize the DiI-labelled cells, while a fluorescein filter set was used to visualize the HNK-1 or neurofilament immunoreactivity. Data from the confocal microscope were stored on removable Bernoulli discs and images were processed using Photoshop on a Macintosh IICi computer. Data from the conventional epifluorescence microscope were recorded photographically.

\section{RESULTS}

\section{Neurofilament immunolabelling of hindbrain neural crest cells}

Because the majority of cranial neural crest cells migrate underneath the ectoderm, the front of expanding neural crest cells can be observed by careful observation of living embryos. After the 7-8 ss, a translucent sheet of cells was seen extending laterally from the dorsal neural tube at the caudal forebrain, midbrain and rostral hindbrain (r1 and r2). At progressive stages, the continuous sheet expanded laterally and ventrally, adopting a shape like a cobra's hood. By the 12-13 ss, neural crest cells were evident in the caudal hindbrain as two streams aligned with $\mathrm{r} 4$ and $\mathrm{r} 6$; these were separated by the otic vesicle at $\mathrm{r} 5$ and a wedge-shaped zone at $\mathrm{r} 3$ that was apparently free of neural crest cells.

The sheet of migrating neural crest cells in the caudal forebrain, midbrain and $\mathrm{r} 1 / 2$ were recognized by the HNK1 antibody (Noden, 1988; Fig. 1B,C), which has been used widely as a marker for trunk neural crest cells (Tucker et al., 

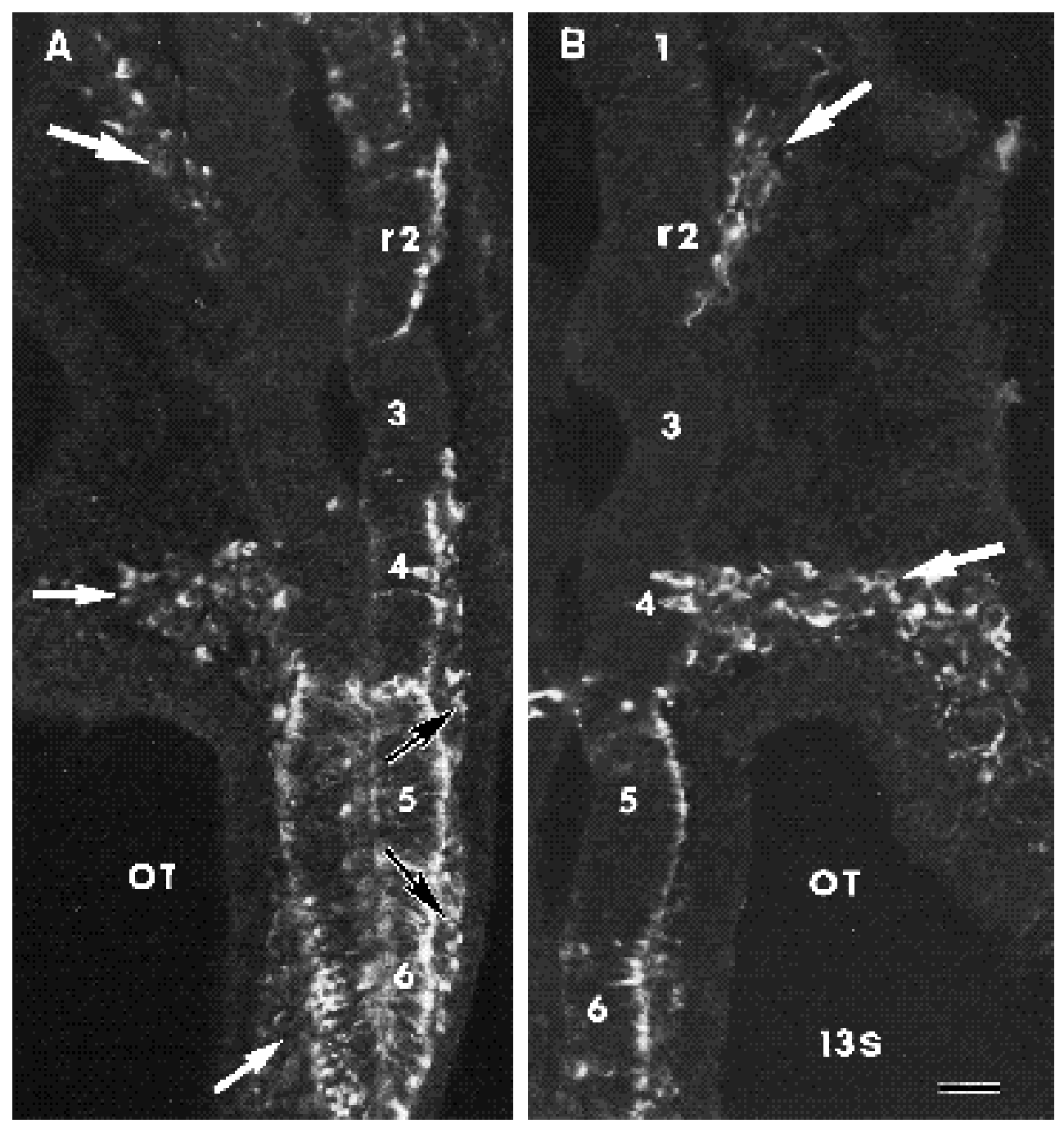

Fig. 3. Longitudinal cryostat sections of a 13 ss embryo encompassing $\mathrm{r} 1$ through $\mathrm{r} 6$ levels of the hindbrain illustrates the apparent trajectory of NF-M+ cells. (A) A section cut near the dorsal roof of r4-6 including the otic vesicle (OT) for orientation. The three primary streams (white arrows) of NF-M+ cells lateral to $\mathrm{r} 2, \mathrm{r} 4$ and $\mathrm{r} 6$ are indicated on the left side. However, at progressively more dorsal levels (shown best on the right side; black arrows), NF-M+ cells were observed between the ectoderm and hindbrain with a continuous thin column of NF$\mathrm{M}+$ cells apparently arising from caudal r3-r6. Note that many premigratory neural crest cells in the dorsal hindbrain of r5 and $\mathrm{r} 6$ are NF-M+. (B) At more ventral levels, the streams of NF-M+ cells lateral to $\mathrm{r} 2$ (arrow; trigeminal) and $\mathrm{r} 4$ (arrow; facial) levels are clearly visible, with apparent gaps at $\mathrm{r} 3$ and $\mathrm{r} 5$. Note that the cells from caudal $\mathrm{r} 2 /$ rostral $\mathrm{r} 3$ appear to move along a sharp rostrolateral trajectory. Bar, $26 \mu \mathrm{m}$.

1984). In contrast, we observed only limited HNK-1 immunoreactivity in the hindbrain region caudal to $\mathrm{r} 2$ at early stages (8-11 ss; Fig. 1C). Only after the 12 ss were HNK-1+ cells visible in increasing numbers extending laterally and ventrally from the level of r4 (Fig. 2E). Surprisingly, an antibody against the non-phosphorylated epitope of neurofilament (NF-M; Lee et al., 1987) serves as a good marker for early neural crest cells in the hindbrain (Fig. 1) and appears several stages before HNK-1 staining in this region of the neural tube. It stains not only hindbrain neural crest cells (both preotic and postotic, including vagal), but also a few cells in the caudal midbrain. In contrast, an antibody to phosphorylated neurofilament appears later and stains only vagal neural crest cells (Payette et al., 1984).

Neurofilament immunoreactive $(\mathrm{NF}-\mathrm{M}+)$ cells were observed first in the dorsal midline at the level of $\mathrm{r} 2$ by the 8-9 ss (Figs 1, 2A). Their position above the neural folds immediately before and during the early phases of neural crest emigration suggests that these immunoreactive cells are precursors of the neural crest. A few NF-M+ cells were observed at other axial levels at this stage (r1, r3, r4 and caudal midbrain), but none were observed in the region of the caudal forebrain or rostral midbrain. In r3 but not other rhombomeres, the neuroepithelial cells of the neural tube were weakly NF-M+, which served as a useful transient marker for $\mathrm{r} 3$ (Fig. 2D). In addition, intense specific immunoreactivity was observed in the early differentiating reticular neuroblasts (Sechrist and Bronner-Fraser, 1991) in the neural tube at $\mathrm{r} 4$ through $\mathrm{r} 8$ (Fig. 2B). At r4 and r5, a multi-layered cap of NF-M+ cells formed in the dorsal midline by the 10-11 ss (Fig. 2B); these were morphologically similar to those at $\mathrm{r} 2$ but slightly delayed in time of appearance. Emigration of NF-M+ cells from the mid- to caudal hindbrain began at the 10-11 ss and increasing numbers emigrated from the neural tube at $\mathrm{r} 4$ and r6 levels between the 12 and 16 ss. In contrast, only spurious HNK1 immunoreactive cells in these same regions were detectable at the 14 ss (Fig. 2E), with comparable numbers of HNK-1+ and NF-M+ cells being evident only by the 16 ss (Fig. 2F).

The overall pattern of NF-M+ neural crest cells in the hindbrain can best be visualized by examining whole-mount stained embryos or longitudinal sections. At the 8-9 ss, NF$\mathrm{M}+$ cells were seen as a continuous unsegmented band along the dorsal midline, from the level of r2-r8 (Fig. 1D,E). At progressive stages, fewer NF-M+ cells were noted in $\mathrm{r} 3$ than other rhombomeres, such that by the $13 \mathrm{ss}, \mathrm{r} 3$ appeared to 

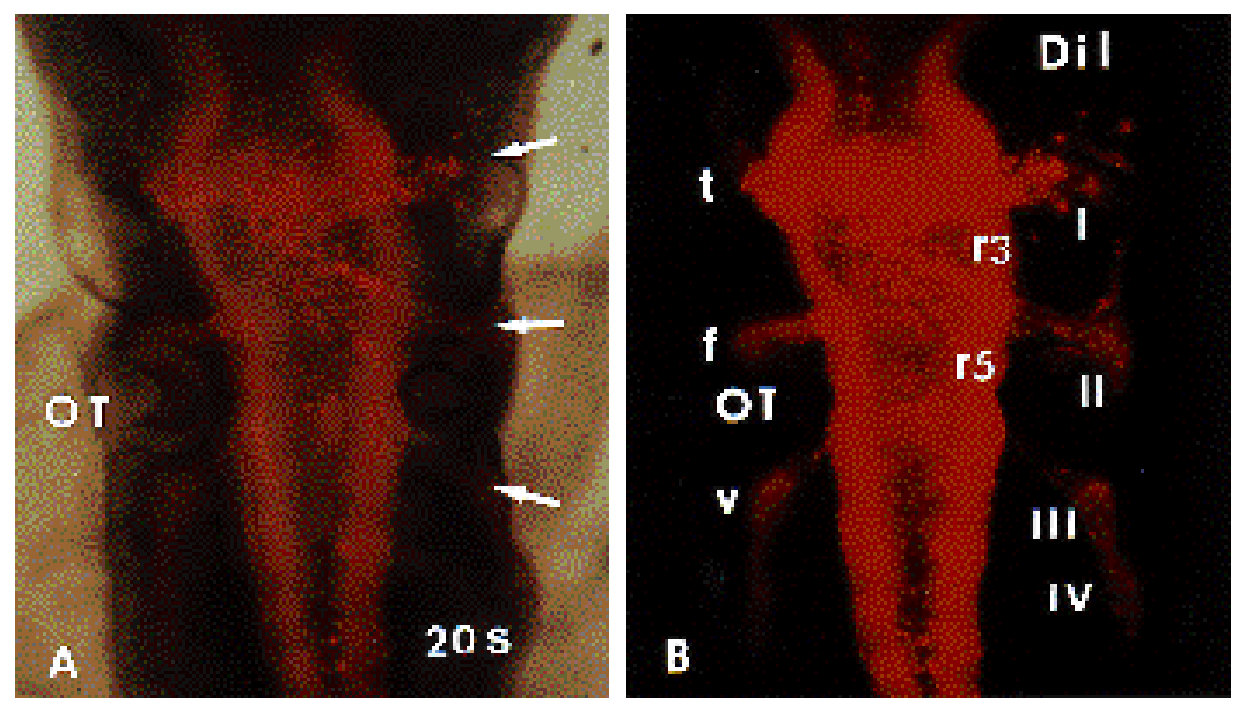

Fig. 4. Fluorescence micrographs of whole mount $(\mathrm{A}, \mathrm{B})$ and transverse sections (C-E) of the hindbrain region of embryos following injection of DiI into the cranial neural tube.

(A) Fluorescence plus bright field and (B) fluorescence micrograph of an embryo which was injected at the 10 ss and examined at the $20 \mathrm{ss}$; three major pathways of DiI-labelled neural crest cells (arrows) emanated from the hindbrain. The trigeminal $(\mathrm{t} ; \mathrm{r} 2)$, facial (f; r4) and vagal (v; r6) streams were observed moving toward branchial arches I, II and III/IV,
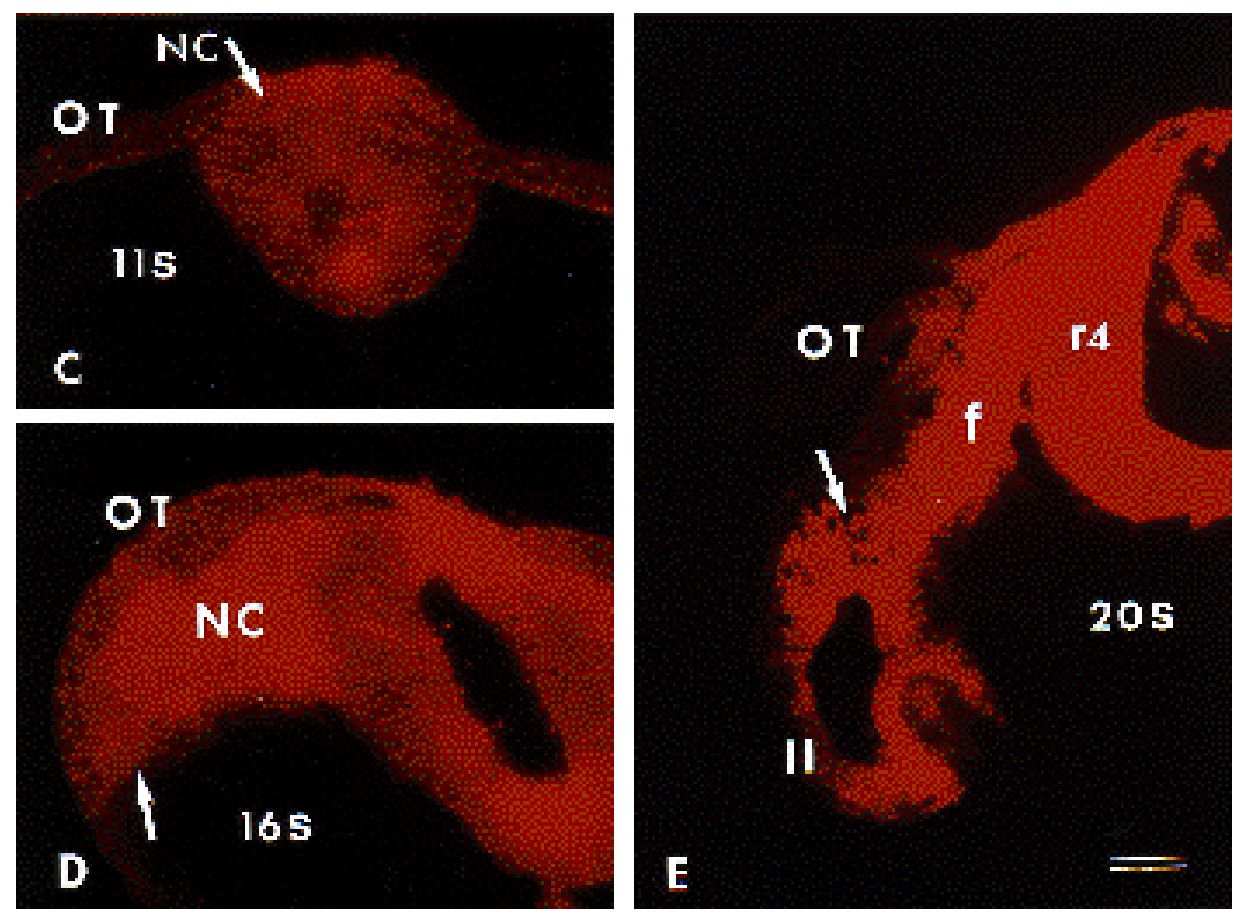
respectively. Note the virtual absence of DiI-labelled cells in the mesenchyme lateral to $\mathrm{r} 3$ and the otic vesicle (OT) lateral to r5. (C) An embryo injected with DiI at the 4 ss and fixed at the 11 ss. In the hindbrain, DiI-labelled cells had recently emigrated and were seen on the dorsal neural tube and apposed to the proximal otic placode (OT) at the r4,5 level (compare with NF-M+ crest cells in Fig. 3C). (D) In an embryo injected with DiI at the 8 ss and fixed at the $16 \mathrm{ss}$, a large number of labelled neural crest cells (NC, arrow) were observed migrating ventrolaterally at the $\mathrm{r} 4$ level, approximately 8 hours later than those pictured in C. (E) Transverse, slightly oblique, sections through an embryo injected with DiI at the 8 ss and fixed at the 20 ss. DiI-labelled cells were observed in the position of future cranial nerves and in the branchial arches. The facial nerve (f) is rostral to the otic vesicle (OT).

Epibranchial placode derived neurons were conspicuous dorsolateral to branchial arch II by the lack of DiI labelling, thus appearing like the small, empty 'holes' (arrow) in the forming geniculate ganglion. Although DiI-labelled neural crest cells were prominent in the branchial arches, these cells had lost NF-M immunoreactivity by this stage. Bar, $70 \mu \mathrm{m}$ in A,B; $34 \mu \mathrm{m}$ in C,D; and $50 \mu \mathrm{m}$ in $\mathrm{E}$.

be largely devoid of NF-M+ cells (Fig. 1E-G). A similar clearing of NF-M+ cells was noted for $\mathrm{r} 5$ at a slightly later stage. In longitudinal sections through 13 ss embryos, few if any cells were observed in the mesenchyme adjacent to r3 or between the neural tube and otic vesicle adjacent to r5, though NF-M+ cells were observed in the small space between r5, the dorsal ectoderm and the otic vesicle (Fig. $3 \mathrm{~A}, \mathrm{~B})$. The changing patterns of neurofilament immunoreactivity suggest that some of the NF-M+ cells that arise in the dorsal midline of $\mathrm{r} 3$ and $\mathrm{r} 5$ are displaced to other levels, eliminated by cell death or lose NF-M immunoreactivity. In contrast to $\mathrm{r} 3$ and $\mathrm{r} 5$, NF-M+ cells were observed continuously in the other rhombomeres during the course of neural crest emigration. NF-M+ neural crest cells arising from $\mathrm{r} 2$ appeared to move in two directions, as described by Noden (1975): dorsolaterally underneath the ectoderm extending into the first branchial arch and ventromedially toward the trigeminal ganglion (Fig. 3). At the level of $\mathrm{r} 4$ and rostral r5 (acousticofacial level), a single large stream of neural crest cells was observed moving dorsolaterally and then ventrally to contribute to ganglionic and second branchial arch (hyoid) structures (Fig. 3). At the level of caudal r5 and r6, neural crest cells appeared to extend caudally before moving ventrolaterally toward the third and fourth branchial arches.

NF-M does not appear to be expressed uniformly by all of the neural crest cells at hindbrain levels. For example, at the 16 ss most, if not all, of the neural crest cells emanating from $\mathrm{r} 4$ and moving into the second branchial arch were NF- 

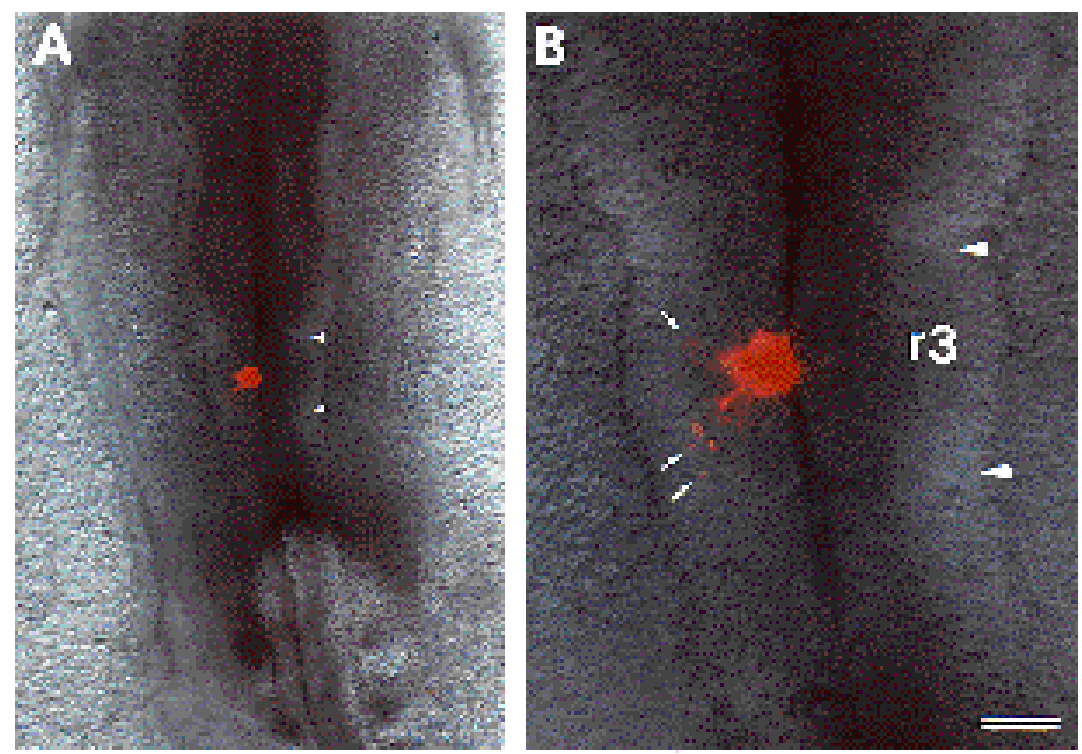

Fig. 5. Confocal microscope image of an embryo fixed 2 hours after receiving a focal injection of DiI into $\mathrm{r} 3$. The injection was performed at the 9 ss and the embryo was fixed at the 10 ss. (A) At lower magnification, the focal injection site is visible within the confines of $\mathrm{r} 3$ (small arrowheads). (B) At higher magnification, a few DiI-labelled cells (small arrows) have already dispersed from the initial injection site, and appear to be migrating both rostrally and caudally. Large arrowheads mark the boundaries of $r 3$. This was a relatively large focal injection compared with the majority performed in this study. Bar, $190 \mu \mathrm{m}$ in A, $65 \mu \mathrm{m}$ in B.
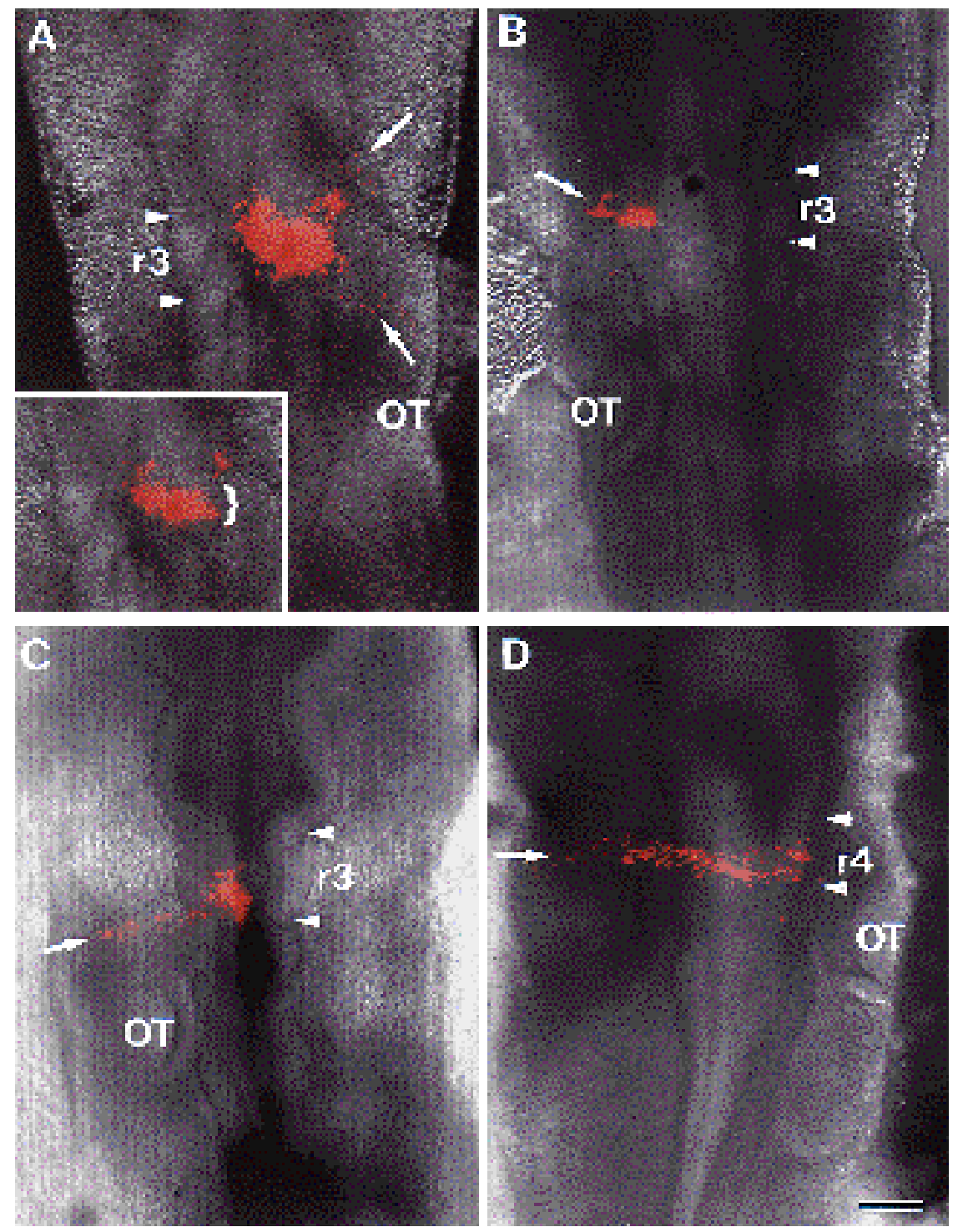

Fig. 6. Confocal microscope images of 18-20 ss embryos receiving focal injections of DiI into the dorsal neural tube at $\mathrm{r} 3$ or $\mathrm{r} 4$ (between arrowheads). (A) An embryo injected at the 9 ss in which two thin streams of DiI-labelled neural crest cells (arrows) have migrated rostrally and caudally to join the $\mathrm{r} 2$ and $\mathrm{r} 4$ streams after emerging from the neural tube at $\mathrm{r} 3$; they appeared to avoid the preotic mesoderm lateral to $\mathrm{r} 3$. (Inset) A single confocal microscope focal plane illustrates that the label within the neural tube of $\mathrm{r} 3$ (bracket) was confined to rostral r3; individual cells in the same plane of section are neural crest cells which have dispersed from the injection site. Arrows indicate rhombomere borders. (B) An embryo that received a small focal injection in $\mathrm{r} 3$ at the 9 ss, in which a group of DiI-labelled cells (arrow) appeared in the mesenchyme lateral to $\mathrm{r} 3$. (C) An embryo injected at the $8 \mathrm{ss}$, in which DiI-labelled cells (arrow) have moved from $\mathrm{r} 3$ in a caudolateral stream rostral to the otic vesicle (OT), fusing with the stream emanating from r4. (D) An embryo injected in $\mathrm{r} 4$ at the $12 \mathrm{ss}$; many DiI-labelled neural crest cells coursed ventrolaterally into branchial arch II (arrow). Bar, $80 \mu \mathrm{m}$. 
$\mathrm{M}+$ (Fig. 2C). By the $25 \mathrm{ss}, \mathrm{NF}-\mathrm{M}+$ cells were observed in branchial arches 3 and 4, but not in arches 1 and 2, a pattern of immunoreactivity consistent with previous observations using antibodies against a neurofilament-related protein or a phosphorylated neurofilament epitope (Ciment and Weston, 1985; Payette et al., 1984). Because all four arches are known to contain neural crest cells, this loss of immunoreactivity suggests either: (1) that NF-M is a transient marker for some populations of migrating neural crest cells; (2) that NF-M+ cells are eliminated by cell death in the first two arches; or, (3) that NF-M immunoreactivity in the first two arches is diminished by the selective proliferation of NF-M negative neural crest cells.

\section{Dil-labelling of the cranial neural tube}

Labelling with the vital dye, DiI, was performed to confirm that the NF-M+ cells at hindbrain levels represented emigrating and migrating neural crest cells. DiI injection into the lumen of the cranial neural tube labels the vast majority of the premigratory neural crest cell population (Serbedzija et al., 1989). By injecting embryos at different stages, both the pattern and the timing of neural crest cell migration was examined in serial sections and in whole mounts by conventional or confocal microscopy.

The DiI-labelled cells appeared to emigrate in a rostrocaudal progression, first at the midbrain and then in the hindbrain. In agreement with the immunolabelling data, DiIlabelled neural crest cells emerged as a uniform array of cells underneath the ectoderm at the level of the midbrain; in contrast, the cells in the hindbrain region emerged somewhat uniformly but quickly segregated into a set of laterally migrating streams of cells (Fig. 4A,B). When scored at the 11-20 ss, neural tube injections of DiI, performed at the 4-8 ss, were found to label the vast majority of hindbrain neural crest cells in the regions shown to be NF-M+ and/or HNK-1+; those regions not recognized by the antibodies, such as the mesenchyme lateral to $\mathrm{r} 3$, contained no DiI-positive cells (Fig. 4A,B). At the 11 ss, some DiIlabelled cells had emigrated from the neural tube in a pattern analogous to that observed for NF-M+ cells (compare Fig. $4 \mathrm{C}$ with Fig. 2B). By the 16 ss, a large number of labelled neural crest cells were observed migrating ventrolaterally (Fig. 4D) and by the 20 ss stage, they were found in all branchial arches and in the presumptive cranial nerves and the cranial ganglia. Placodally derived neurons already had begun to infiltrate the neural crest-derived cell aggregates, appearing as unlabelled areas within the otherwise DiIpositive ganglionic primordium (Fig. 4E). The large number of DiI-labelled cells in branchial arches 1 and 2 demonstrates that the loss of neurofilament immunoreactivity from these regions was not due to a loss of the neural crest cells themselves; instead, it appears that the absence results from the loss of the NF-M marker from cells that expressed it earlier.

Because injection of DiI into the neural tube cannot label those neural crest cells that have already emigrated, injecting dye at progressively later stages offers a direct assay of the timing of neural crest emigration (Serbedzija et al., 1989). Using this approach, we confirmed the time course of neural crest cell emigration previously established for various cranial levels (Anderson and Meier, 1981;
Tosney, 1982; Cochard and Coltey, 1983; Lumsden et al., 1991). Injections of DiI at the 10-18 ss resulted in progressively fewer labelled neural crest cells at hindbrain levels. Within the hindbrain, there was a rostrocaudal gradient in both initiation and cessation of neural crest migration. For example, injection of DiI into the neural tube at the 12-14 ss resulted in only a small number of DiI-labelled neural crest cells emerging at the $\mathrm{r} 2$ level, where emigration was nearly complete; in contrast, many more DiI-labelled cells were observed at $\mathrm{r} 4$ and $\mathrm{r} 6$ levels, where emigration was still underway. For injections made at the 17-18 ss, only a few labelled cells were observed emerging from the caudal hindbrain at the r6 level, suggesting that caudal cranial neural crest cell emigration was nearly completed by this stage. Thus, emigration of neural crest cells from the hindbrain begins at the 8-9 ss and is nearly complete by the $17-18$ ss.

The results obtained by labelling the cranial neural tube with DiI confirm and extend the patterns of neural crest migration in the hindbrain inferred from neurofilament immunoreactivity. Few if any neural crest cells were observed lateral to $\mathrm{r} 3$ and $\mathrm{r} 5$. However, whole neural tube injections of DiI cannot determine the axial level of origin of the DiI-labelled neural crest cells in the periphery. Therefore, the data above cannot discriminate between two opposed explanations of the neural crest cell-free space lateral to r3 and r5: (1) no neural crest cells arise from $\mathrm{r} 3$ or $\mathrm{r} 5$, and an orderly pattern of migration maintains this segmented pattern into the periphery; or, (2) neural crest cells originate from both $\mathrm{r} 3$ and $\mathrm{r} 5$ but the cells are diverted to other axial levels before they course into the periphery.

\section{Focal labelling of $r 3$ and $r 5$ with Dil}

To determine the contributions of $\mathrm{r} 3$ and $\mathrm{r} 5$ to the neural crest, we performed focal injections of DiI into the dorsal neural tube of embryos ranging from the 3 to $15 \mathrm{ss}$. The goal of these injections was to label regions of neural tube that were smaller than, and completely contained within, single rhombomeres, so that the contribution of each rhombomere to the neural crest could be evaluated unambiguously. The size and position of each injection was scored both at the time of injection and fixation (14-28 ss). Confocal microscopy shows the initial positioning and restricted size of a focal injection (Fig. 5). The case illustrated is one of the largest injections performed, in an embryo injected at the 9 ss and fixed 2 hours later at the 10 ss. The initial focal injection site is clearly visible as a spot of bright DiIlabelling within the confines of $r 3$ (Fig. 5B). As early as 2 hours postinjection, a few individual DiI-labelled cells appeared to be migrating away from the initial injection, beginning to course both rostrally and caudally along the dorsal neural tube (Fig. 5B). At the stage of fixation, both the rhombomere boundaries and the streams of migrating neural crest cells were clearly visible; the position of the labelled cells that remained within the neural tube was used to evaluate the position of the injection. For the present study, we accepted only injections contained within rhombomere borders at both the time of injection and fixation.

Focal injections into $\mathrm{r} 1, \mathrm{r} 2, \mathrm{r} 4$ or $\mathrm{r} 6$ gave rise to a pattern of labelled cells consistent with previous studies (Lumsden et al., 1991). The cells migrated away from the injection site, 
Table 1. Contribution of hindbrain neural crest cells to branchial arches as shown by focal DiI injections into specific rhombomeres

\begin{tabular}{lccccccc}
\hline & \multicolumn{6}{c}{$\begin{array}{c}\text { Contributions to branchial } \\
\text { arches }\end{array}$} \\
\cline { 3 - 5 } $\begin{array}{l}\text { Rhombomere } \\
\text { injected }\end{array}$ & $\begin{array}{c}\text { Total } \\
\text { number }\end{array}$ & I & I+II & II & II+III & III & $\begin{array}{c}\text { No } \\
\text { migration }\end{array}$ \\
\hline r1 & 2 & 2 & & & & & \\
r2 & 8 & 8 & & & & & \\
r3 & 18 & 2 & 5 & 9 & & & 2 \\
r4 & 5 & & & 5 & & & \\
r5 & 20 & & & 3 & 9 & 5 & 3 \\
r6 & 6 & & & & & $6^{*}$ &
\end{tabular}

*Some of the r6 injections also contributed cells to branchial arch IV.

coursing ventrolaterally through the adjacent mesenchyme into either the first, second (see Fig. 6D) or third branchial arches, respectively (Table 1). The labelled cells in the neural tube remained as a somewhat coherent mass, validating their use as a measure of the position of the DiI injection. A few embryos were fixed and sectioned at 5 days postinjection at which time light DiI labelling was detectable in some neural crest derivatives.

Injection of $\mathrm{r} 3$ prior to the 10 ss typically resulted in small streams of DiI-labelled cells joining the $\mathrm{r} 2$ and/or $\mathrm{r} 4$ streams external to the neural tube, suggesting they had emigrated. 18 embryos received small focal injections that appeared to be within the confines of $\mathrm{r} 3$ at the time of fixation. 16 of these gave rise to migrating neural crest cells, although the number of neural crest cells generated by $\mathrm{r} 3$ was somewhat less than from other rhombomeres similarly labelled (Table 1; Fig. 6). To confirm that our injections were localized only to $\mathrm{r}$, we carefully analyzed serial optical sections from the most dorsal to the most ventral levels of the neural tube using the confocal microscope. This permitted us to distinguish the label in the neuroepithelium of the neural tube from the neural crest to which its gives rise. These observations showed unambiguously that the DiI labelling within the neural tube was within the confines of $r 3$ in nine of the embryos receiving focal injections. As expected from the considerable dispersion of clonally related cells within a single rhombomere reported previously (Fraser et al., 1990), the region of labelled cells within the neuroepithelium was dramatically larger at the time of fixation than at injection. Interestingly, we observed a slight bias in this dispersion, with the descendants appearing to shift caudally in position, in progressively older embryos.

In embryos fixed at later stages, the DiI-labelled neural crest cells emerging from $\mathrm{r} 3$ deviated around the adjacent mesoderm, migrating rostrally or caudally (Fig. 6A,C). This contrasts with r4 (Fig. 6D), from which neural crest cells migrated directly laterally into the adjacent mesoderm. After DiI injection into $\mathrm{r}$, two clear pathways were observed (Fig. 6A,C): (1) a rostroventral stream of cells extending toward the first branchial arch, which joined the stream of neural crest cells arising from $\mathrm{r} 2$; and, (2) a caudoventral stream extending toward the second branchial arch, which joined with the stream of neural crest cells derived from $\mathrm{r} 4$. Labelled neural crest cells were rarely observed in the mesenchyme immediately lateral to $\mathrm{r} 3$. Fig. 6B shows an exceptional case in which a few labelled cells were located imme- diately lateral to $\mathrm{r} 3$. Although the majority of focal injections contributed neural crest cells to one branchial arch only, 5/16 embryos yielded DiI-labelled neural crest cells in both arches I and II (Table 1). These results suggest that $\mathrm{r} 3$ can give rise to a small but significant number of neural crest cells that migrate either rostrally or caudally before they course laterally, creating a neural crest cell free zone lateral to $\mathrm{r} 3$.

Similar to $\mathrm{r} 3$, labelled cells arose from $\mathrm{r} 5$ but coursed rostrally or caudally before moving laterally to populate branchial arches II and III. Unlike injections into r3, injections into 5 gave rise to larger numbers of labelled neural crest cells that circumnavigated the otic vesicle and coursed into the periphery; 20 embryos received small focal injections of DiI, of which 17 injections (made between the 8 and 17 ss) gave rise to numerous labelled neural crest cells external to the neural tube (Table 1). When carefully analyzed by confocal microscopy, the DiI label was confined unequivocally to the neural tube at $\mathrm{r} 5$ in 8 of these embryos (Fig. 7A, inset). DiI-labelled neural crest cells extended in two directions around the otic vesicle (Fig. 7A,B): (1) rostrally into the second branchial arch, joining with the stream of neural crest cells arising from $\mathrm{r} 4$; and, (2) caudally toward the third branchial arch, merging with neural crest cells arising from r6. The majority of embryos (9/17) had DiI-labelled neural crest cells contributing to both branchial arches II and III (Table 1), though some smaller injections contributed to only one or the other arch depending on the rostrocaudal position of the injection. The results of focal injections of DiI are summarized in Table 1 and Fig. 8.

Selected embryos were sectioned in either the transverse or longitudinal plane after receiving a focal injection at $\mathrm{r} 3$ or $\mathrm{r} 5$. In sections, the ectoderm forming the first branchial groove was juxtaposed to the rostral portion of $r 3$ (data not shown). This site of apposition corresponds to the light wedge-shaped area adjacent to $\mathrm{r} 3$ in living embryos and the unlabelled region observed after injection of DiI into the whole neural tube. At the level of r5, there is a small cylindrical column between the dorsal portion of the neural tube, the ectoderm and the apposed otic vesicle that contains numerous DiI-labelled neural crest cells; in contrast, no DiIlabelled cells are observed ventral to the site where the otic vesicle abuts the neural tube (data not shown). These observations are consistent with the possibility that the first branchial cleft ectoderm/mesoderm and the otic vesicle may act as barriers for migrating neural crest cells.

\section{DISCUSSION}

By combining immunocytochemistry, using HNK-1 and neurofilament antibodies, with vital dye labelling by DiI injections, our experiments follow the population of cranial neural crest cells. A consistent story of neural crest cell migration in the head emerges, which is summarized in Fig. 8. Emigration of neural crest cells primarily occurs in a rostral to caudal sequence, first initiating in the midbrain after the 6-7 ss. Perhaps because neural tube closure in the forebrain lags behind that in the midbrain, there is also a short caudal to rostral sequence of initiation forward from 

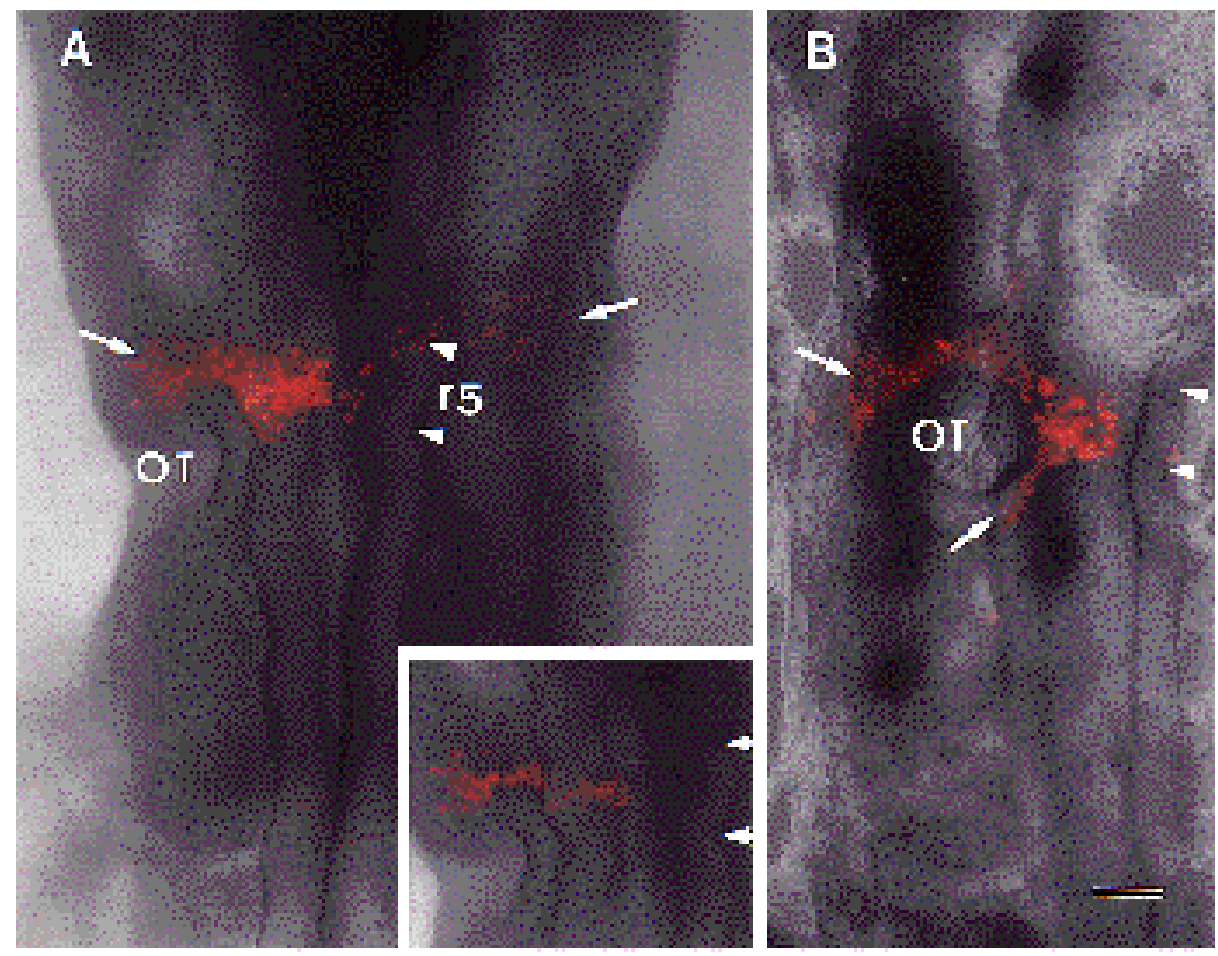

Fig. 7. Confocal microscope images of 16-18 ss embryos receiving focal injections of DiI into the dorsal neural tube of $r 5$ (between arrowheads).

(A) An embryo injected at the $11 \mathrm{ss}$ in which DiI-labelled neural crest cells (arrow) have migrated bilaterally in an arc-like pattern rostral to the otic vesicle (OT), fusing with neural crest cells emanating from $\mathrm{r} 4$; (inset) the DiI-labelling was well within the confines of $\mathrm{r} 5$, at the focal levels within the neural tube. (B) An embryo injected at the $11 \mathrm{ss}$, in which the DiIlabelled cells (arrows) have moved both rostrally and caudally around the otic vesicle, fusing with neural crest cells derived from r4 and r6. Bar, 80 $\mu \mathrm{m}$. the midbrain to the caudal forebrain (Noden, 1975). The neural crest cells arising from the caudal forebrain, midbrain and rostral hindbrain ( $\mathrm{r} 1$ and $\mathrm{r} 2$ ) expand outward as a wave, forming a front of cells resembling a cobra's hood on the cranial neural tube. These cells migrate to populate the frontonasal processes and the first branchial arch. In the more caudal hindbrain, the pattern of neural crest cell migration is segmented, with no neural crest cells in the mesenchyme lateral to $\mathrm{r} 3$ or in the region of the otic vesicle lateral to $\mathrm{r} 5$ (Anderson and Meier, 1981; Tosney, 1982; Noden, 1988; Lumsden et al., 1991).

Our results demonstrate that single immunological reagents are inadequate to follow the migration of cranial neural crest cells in the avian embryo. Although the HNK1 antibody (Tucker et al., 1984) has been used successfully to follow some events in cranial neural crest development (Noden, 1988), it is not adequate to follow the earliest phases of neural crest migration in the hindbrain, as antigenicity becomes conspicuous only after the 12 ss at this level. Fortunately, an antibody against a non-phosphorylated neurofilament epitope (RMO 270.3; Lee et al., 1987) marked this early population of hindbrain neural crest cells. Neurofilament immunoreactivity is dynamic, first appearing in a population of cells located at the dorsal midline prior to the onset of neural crest cell emigration (8 ss), remaining present throughout the migratory phase and eventually disappearing from neural crest-derived cells in the first and second branchial arches. To validate that this antibody marks neural crest cells, vital labelling of the entire neural tube with the lipophilic dye, DiI, was used as an independent marker for the neural crest (Serbedzija et al., 1989). DiI-labelled cells migrated away from the neural tube in the pattern predicted by the combined immunoreactivity of the HNK-1 and neurofilament antibodies. Cells emanated uniformly from the neural tube at the levels of the caudal forebrain, midbrain and rostral hindbrain; neural crest migration was segmentally organized in the caudal hindbrain, with cells largely absent from the region lateral to $\mathrm{r} 3$ and $\mathrm{r} 5$.

There are two broad classes of explanation that could account for the absence of neural crest cells from the mesoderm lateral to $\mathrm{r} 3$ and the otic vesicle region lateral to $\mathrm{r} 5$, as reported here and in previous studies (c.f. Noden, 1975; Anderson and Meier, 1981; D'Amico-Martel and Noden, 1983; Lumsden et al., 1991). First, these rhombomeres may fail to generate viable neural crest cells. Second, these segments may give rise to neural crest cells, which are then restricted in their migration by factors present in the local microenvironment. Previous experiments have provided data that support both scenarios. Based on scanning electron microscopy, Anderson and Meier (1981) reported that neural crest cells are generated at all levels of the hindbrain, though fewer appeared from r3. These investigators suggested that cranial neural crest migration is intimately interlinked with mesoderm units, termed somitomeres. At the level of $\mathrm{r} 3$, they noted that neural crest cells fail to migrate over somitomere 5 but move rostrocaudally to join the main otic streams. Using quail/chick chimerae, Couly and LeDouarin (1990) suggested that neural crest cells derived from a region including $\mathrm{r} 5$ contribute to the second branchial arch. In contrast, the DiI-labelling experiments of Lumsden and colleagues (1991) suggested that neither r3 nor r5 produced migrating neural crest cells. The results presented here resolve some of these differences. Our focal injections of DiI, combined with HNK-1 and NF-M immunoreactivities, suggest that neural crest cells are generated by all levels of the neural axis at early stages with the exception of the rostral forebrain. In particular, both $\mathrm{r} 3$ and $\mathrm{r} 5$ were found to give rise to neural crest cells that migrated along pathways, 


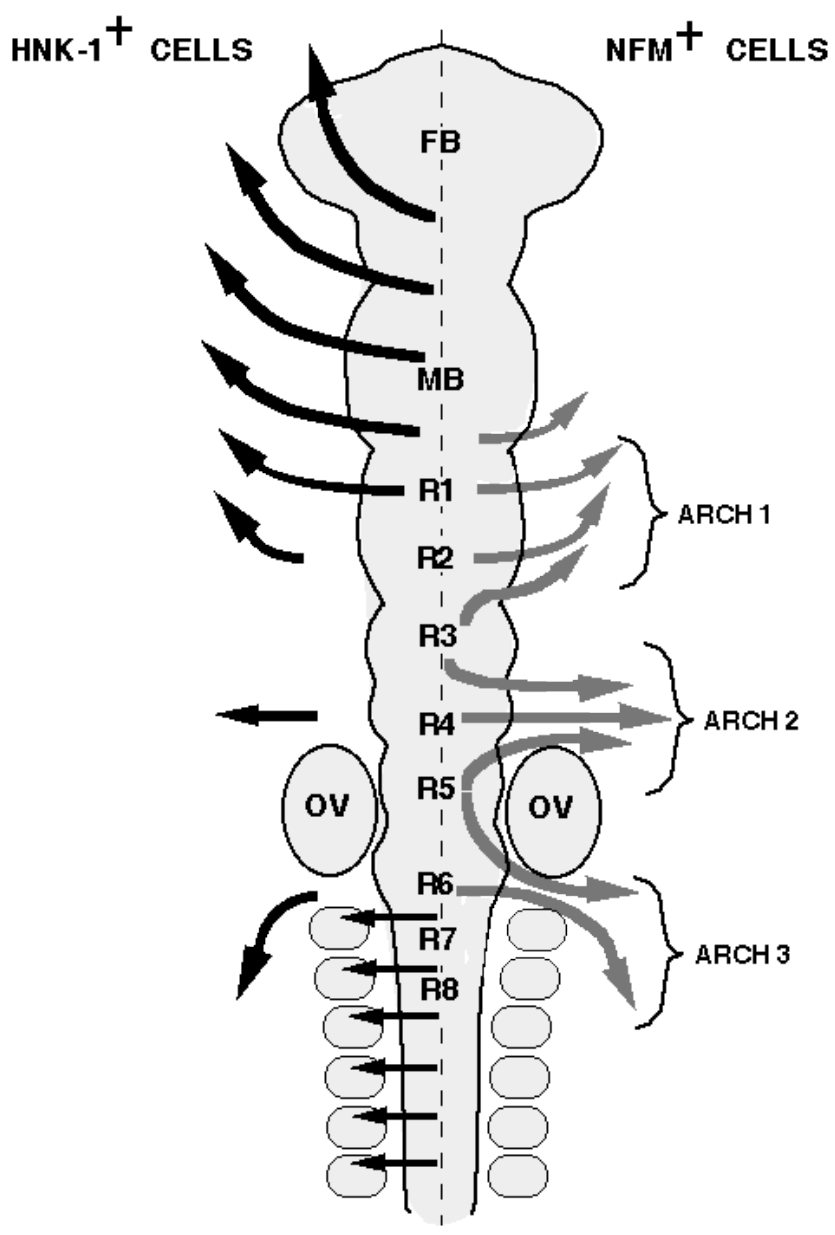

Fig. 8. Schematic diagram summarizing the distribution of HNK$1+$ (left arrows) and neurofilament (NF-M+; right arrows) immunoreactive cells in the cranial region. Our results suggest that neural crest cells originate from all axial levels but do not enter the region adjacent to $\mathrm{r} 3$ or the otic vesicle lateral to $\mathrm{r} 5$. Because a wedge-shape of ectoderm of the first branchial groove closely apposes $\mathrm{r} 3$ and the otic vesicle apposes $\mathrm{r} 5$, these lateral regions and/or the adjacent cranial mesenchyme may act as barriers to migration.

which deviated around the adjacent mesoderm or otic vesicle and contributed to branchial arches I and II, in the case of r3, and II and III in the case of r5. In contrast, neural crest cells from $\mathrm{r} 2$ and $\mathrm{r} 4$ contribute to a single branchial arch; furthermore, neural crest cells from r4 migrate laterally in a direct pathway into branchial arch 2. Although r3 appears to produce fewer neural crest cells than other rhombomeres, this alone is insufficient to account for the segmental arrangement of neural crest cells. These positive immunocytochemistry and DiI-labelling results agree with previous studies using acetylcholinesterase as a marker for premigratory and early migrating neural crest cells, which demonstrated that neural crest cells emerged uniformly from all levels of the neuraxis (Cochard and Coltey, 1983). Although cell death may play a role in reducing the number of neural crest cells from $\mathrm{r} 3$ and $\mathrm{r} 5$, it cannot account for the complete absence of cells. Of course, it remains possible that some of the differences between the results of these various studies result from strain differences in the embryos used.
However, it seems likely that the pattern reported here is more general. Recent experiments on cranial neural crest migration in the mouse embryo (Serbedzija et al., 1992) show a similar pattern, in which all segments of the hindbrain give rise to neural crest cells, which then migrate in a segmented fashion into the periphery.

A small but significant fraction of our focal injections into r3 and r5 failed to give rise to neural crest cells. While we have emphasized the positive result of finding DiI-labelled neural crest cells emanating from the majority of our $r 3$ or r5 injections, it is worthwhile to consider the possible explanations for these negative findings. First, we chose to score only small injections which gave rise to neural tube cells clearly restricted to a single rhombomere; such small injections, made slightly too far ventral would fail to mark neural crest progenitors. Second, r3 gives rise to a smaller population of neural crest cells, which complete their emigration earlier than the other rhombomeres; this makes it more likely to miss labelling a significant fraction of the neural crest progenitors. Third, regional differences in cell death in the hindbrain (Lumsden et al., 1991; Jeffs et al., 1992) may reduce the numbers of neural crest cells at r3 and r5. Jeffs and colleagues (1992) have noted prominent numbers of dying cells at the dorsal midline of r3 and r5; interestingly, cell death is maximal at the 13-15 ss, by which time neural crest emigration is nearing completion. By these stages, we noted a marked reorganization and clearing of NF-M+ cells from the $\mathrm{r} 3$ region of the hindbrain. Finally, we cannot rule out the possibility that local damage to the neural tube may account for the small number of negative results in our study. Based on our observation that some DiI-labelled cells originating from r3 and r5 populate neural crest derivatives, cell death alone cannot account for the observed distribution of neural crest cells. While it is difficult to interpret negative findings definitively, any or all of the above may be responsible for our minority results and the majority result of Lumsden and colleagues (1991).

Because our findings show that the segmental migration pattern of the neural crest in the hindbrain is formed out of cells generated from all rhombomeres, a significant role for the periphery in establishing the migration pattern is suggested. One likely restriction to migration is the otic vesicle, which has been suggested to be a mechanical barrier to migrating neural crest cells (Anderson and Meier, 1981; Tosney, 1982; Noden, 1988; Lumsden et al., 1991). Just as the otic vesicle may serve as a physical barrier for migration lateral to $r 5$, there is close apposition between rostral $r 3$ and the adjacent ectoderm as the first (hyomandibular) branchial groove invaginates, making this a potential impediment to migration. However, this cannot and should not be taken as evidence against any regionalization of neural crest cells along the neural axis. In fact, the present results show that there are distinct differences in cell behavior, antigenicity, and cell number along the neural axis. These differences, combined with the differences in cell death (Lumsden et al., 1991; Jeffs et al., 1992), suggest the presence of segmental differences that are either intrinsic or emerge through interaction with other segments. Other studies offer evidence for inherent programming for some populations of cranial neural crest cells based on their level of origin. For example, transplantation of the neural crest cells that normally 
populate the first branchial to the level of the second branchial arch results in formation of first arch structures in place of the second arch (Noden, 1983). Thus, the cells that constructed or guided the construction of the scored structures possessed and maintained some arch-specific traits. In addition, following an ablation of the midbrain or hindbrain neural crest, the neural crest cells rostral or caudal to the ablation do not compensate for the missing tissue; rather, the neural tube cells ventral to the ablation reform the removed neural crest (Scherson et al., 1993), again suggesting regional differences that direct the compensatory events. Finally, recent molecular data in avians (Gardner et al., 1988; Davis et al., 1991) and other vertebrates (Wilkinson et al., 1989; Hunt et al., 1991) show clear axial non-equivalencies in the cells of the cranial neural tube. While such molecular data argues strongly for axial addresses, our data on cell migration indicates the need for some rethinking of the mechanisms that maintain these expression patterns. Rhombomere 3 contributes neural crest cells to both the first and second branchial arches; r5 contributes to the second and third arches (Table 1). Because the expression pattern of some transcription factors is different in the rhombomeres and the arches, the molecular pattern cannot be a prepattern, established by heredity alone; instead, the expression pattern must be dynamically maintained and adjusted through interactions with other cells and tissues. However, some transcription factors may be carried by migrating neural crest cells; for example, some neural crest cells migrating caudally from r5 express Krox 20 during their migration (Sham et al., 1993).

Previous studies have noted that some subsets of the neural crest express neurofilament proteins or neurofilament associated proteins, and have used this expression to analyze regional differences in developmental fate. For example, a population of migrating cranial neural crest cells that expresses the NAPA-73 antigen (a neurofilament associated protein; Ciment and Weston, 1985) is found in the caudal, but not the rostral branchial arches. When assayed in culture, the NAPA-positive cells gave rise to neurons, but not melanocytes (Ciment and Weston, 1985). In addition, Payette and colleagues (1984) noted that vagal neural crest cells, but not those at other axial levels, expressed an epitope present on phosphorylated neurofilament proteins. The neurofilament antibody used here recognizes a non-phosphorylated epitope which appears both earlier and in a broader distribution than either the NAPA-73 antigen or phosphorylated neurofilament epitope. In our study, the antibody is used, not as a marker for the analysis of cell fate, but as an adjunct to HNK-1 antibody to permit us to recognize the majority of neural crest cells at cranial levels.

In conclusion, our data confirm that neural crest cell migration is non-segmented in the midbrain but is segmented in the hindbrain (Noden, 1975; Lumsden et al., 1991). The absence of cells in the mesoderm lateral to $r 3$ and otic vesicle lateral to $\mathrm{r} 5$ is not due merely to those segments failing to give rise to neural crest cells. Similarly, in the trunk, previous studies have demonstrated that the segmental patterning of the peripheral nervous system does not result from the absence of neural crest cells from some neural tube levels. Instead, grafting experiments (Keynes and Stern, 1984; Teillet et al., 1987; Bronner-Fraser and
Stern, 1991) and ablation studies (Lewis et al., 1981; Kalcheim and LeDouarin, 1986) suggest that the somites are responsible for segmentation of both motor axons and neural crest cells, perhaps due to an inhibitory cue from the caudal sclerotome (Stern et al., 1986; Davies et al., 1990). The distribution of DiI-labelled cells at the levels of the hindbrain suggests that the segmental pattern of cranial neural crest cell migration results (at least in part) from interference by the adjacent otic vesicle and the preotic mesoderm or ectoderm of the first branchial groove. An intriguing possibility is that the segmental pattern of neural crest cell migration in the hindbrain results from either inhibitory or attractive signals from the environment, similar to those in the trunk region (Keynes and Stern, 1984; Bronner-Fraser and Stern, 1991).

We thank Mary Flowers for excellent technical assistance and Dr Mark Selleck and John Wolf for help with some of the DiI injections. We greatly appreciate the critical comments of Drs Andrew Lumsden, Mark Selleck and Claudio Stern on the manuscript. This study was supported by USPHS HD-25138 to M. B.-F. and HD29304 to S. E. F.

\section{REFERENCES}

Anderson, C. and Meier, S. (1981). The influence of the metameric pattern in the mesoderm on migration of cranial neural crest cells in the chick embryo. Dev. Biol. 85, 385-402.

Bronner-Fraser, M. and Stern, C. (1991). Effects of mesodermal tissues on avian neural crest cell migration. Dev. Biol. 143: 213-217.

Ciment, G. and Weston, J. A. (1985). Segregation of developmental abilities in neural crest-derived cells: identification of partially restricted intermediate cell types in the branchial arches of avian embryos. Dev. Biol. 111, 73-83.

Cochard, P. and Coltey, P. (1983). Cholinergic traits in the neural crest: Acetylcholinesterase in crest cells of the chick embryo. Dev. Biol. 98, 221-238.

Couly, G. and LeDouarin, N. (1990). Head morphogenesis in embryonic chimeras: evidence for a segmental pattern in the ectoderm corresponding to the neuromeres. Development 108, 543-558.

D'Amico-Martel, A. and Noden, D. (1983). Contributions of placodal and neural crest cells to avian cranial peripheral ganglia. Am. J. Anat. 166, 445-468.

Davies, J., Cook, M., Stern, C. D. and Keynes, R. J. (1990). Isolation from chick somites of a glycoprotein that causes collapse of dorsal root ganglion growth cones. Neuron 4, 11-20.

Davis, C. A., Holmyard, D. P., Millen, K. J. and Joyner, A. L. (1991). Examining pattern formation in mouse, chicken and frog embryos with and En-specific antiserum. Development 111, 287-298.

Fraser, S., Keynes, R. and Lumsden, A. (1990). Segmentation in the chick embryo hindbrain is defined by cell lineage restrictions. Nature 334, 431435.

Gardner, C. A., Darnell, D. K., Poole, S. J., Ordahl, C. P. and Barald, K. F. (1988). Expression of engrailed-like gene during development of the early chick nervous system. J. Neurosci. Res. 21, 426-437.

Hamburger, V. and Hamilton, H. (1951). A series of normal stages in the development of the chick embryo. J. Morphol. 88, 49-92.

Honig, M. and Hume, R. I. (1984). Fluorescent carbocyanine dyes allow living neurons of identical origin to be studied in long-term cultures. $J$. Cell Biol. 103, 171-187.

Hunt, P., Gulisano, M., Cook, M., Sham, M.-J., Faiella, A., Wilkinson, D., Boncinelli, E., and Krumlauf, R. (1991). A distinct Hox code for the branchial region of the vertebrate head. Nature 353, 861-864.

Jeffs, P., Jaques, K. and Osmond, M. (1992). Cell death in cranial neural crest development. Anat. Embryol. 185, 583-588.

Johnston, M. C. (1966). A radioautographic study of the migration and fate of cranial neural crest cells in the chick embryo. Anat. Rec. 156, 143-156. Kalcheim, C. and Le Douarin, N. M. (1986). Requirement of a neural tube 
signal for the differentiation of neural crest cells into dorsal root ganglia. Dev. Biol. 116, 451-466.

Keynes, R. J. and Stern, C. D. (1984). Segmentation in the vertebrate nervous system. Nature (London) 310, 786-789.

LeDouarin, N. M. (1973). A biological cell labeling technique and its use in experimental embryology. Dev. Biol. 30, 217-222.

LeDouarin, N. M. (1982). The Neural Crest. Cambridge, UK: Cambridge University Press.

LeDouarin, N. M. (1986). Cell line segregation during peripheral nervous system ontogeny. Science 231, 1515-1522.

LeDouarin, N. M. and Teillet, M. A. (1974). Experimental analysis of the migration and differentiation of neuroblasts of the autonomic nervous system and of neuroectodermal mesenchymal derivatives, using a biological cell marking technique. Dev. Biol. 41, 162-184.

LeLievre, C. and LeDouarin, N. (1975). Mesenchymal derivatives of the neural crest; analysis of chimeric quail and chick embryos. J. Embryol. Exp. Morphol. 34, 125-154.

Lewis, J., Chevalier, A., Kieny, M. and Wolpert, L. (1981). Muscle nerve branches do not develop in chick wings devoid of muscle. J. Embryo. Exp. Morphol. 64, 211-232.

Lee, V., Carden, M., Schlaepfer, W. and Trojanowski, J. (1987). Monoclonal antibodies distinguish several differentially phosphorylated states of the two largest rat neurofilament subunits (NF-H and NF-M) and demonstrate their existence in the normal nervous system of adult rats. $J$. Neurosci. 7, 3474-3489.

Lumsden, A., Sprawson, N. and Graham, A. (1991). Segmental origin and migration of neural crest cells in the hindbrain region of the chick embryo. Development 113, 1281-1291.

Noden, D. M. (1975). An analysis of the migratory behavior of avian cephalic neural crest cells. Dev. Biol. 42, 106-130.

Noden, D. M. (1978a). The control of avian cephalic neural crest cytodifferentiation. I. Skeletal and connective tissues. Dev. Biol. 67, 296312.

Noden, D. M. (1978b). The control of avian cephalic neural crest cytodifferentiation. II. Neural Tissues. Dev. Biol. 67, 313-329.

Noden, D. M. (1983). The role of the neural crest in patterning of avian cranial skeletal, connective and muscle tissues. Dev. Biol. 96, 144165 .

Noden, D. M. (1988). Interactions and fates of avian craniofacial mesenchyme. Development 103 Supplement, 121-140.

Payette, R. F., Bennett, G. S. and Gershon, M. D. (1984). Neurofilament expression in vagal neural crest-derived precursors of enteric neurons. Dev. Biol. 105, 273-287.

Rickmann, M., Fawcett, J. W. and Keynes, R. J. (1985). The migration of neural crest cells and the growth of motor axons through the rostral half of the chick somite.J. Embryol. Exp. Morphol. 90, 437.

Scherson, T., Serbedzija, G., Fraser, S. and Bronner-Fraser, M. (1993). Regulative capacity of the cranial neural tube and neural crest. Development 118 (in press).

Sechrist, J. and Bronner-Fraser, M. (1991). Birth and differentiation of reticular neurons in the chick hindbrain; Ontogeny of the first neuronal population. Neuron 7, 947-963.

Serbedzija, G., Bronner-Fraser, M. and Fraser, S. E. (1989). Vital dye analysis of the timing and pathways of avian trunk neural crest cell migration. Development 106, 806-816.

Serbedzija, G., Fraser, S. E., and Bronner-Fraser, M. (1990). Pathways of trunk neural crest cell migration in the mouse embryo revealed by vital dye analysis. Development 108, 605-612.

Serbedzija, G., Fraser, S. E. and Bronner-Fraser, M. (1992). Vital dye analysis of cranial neural crest cell migration in the mouse embryo. Development 116, 297-307.

Sham, M. H., Vesque, C., Nonchev, S., Marshall, H., Frain, M., Das Gupta, R., Whiting, J., Wilkinson, D., Charnay, P. and Krumlauf, R. (1993). The zinc finger gene Krox 20 regulates Hox B2 (Hox 2.8) during hindbrain segmentation. Cell 72, 183-196.

Stern, C. D., Sisodiya, S. M. and Keynes, R. J. (1986). Interactions between neurites and somite cells: Inhibition and stimulation of nerve growth in the chick embryo. J. Embryol. Exp. Morph. 91, 209-226.

Teillet, M.-A., Kalcheim, C. and LeDouarin, N. M. (1987). Formation of the dorsal root ganglion in the avian embryo: segmental origin and migratory behavior of neural crest progenitor cells. Dev. Biol. 120, 329347.

Tosney, K. W. (1982). The segregation and early migration of cranial neural crest cells in the avian embryo. Dev. Biol. 89, 13-24.

Tucker, G. C., Aoyama, H. Lipinski, M., Tursz, T. and Thiery, J. P. (1984). Identical reactivity of monoclonal antibodies HNK-1 and NC-1: Conservation in vertebrates on cells derived from the neural primordium and on some leukocytes. Cell Differ. 14, 223-230.

Vincent, M., and Thiery, J. P. (1984). A cell surface marker for neural crest and placodal cells: further evolution in peripheral and central nervous system. Dev. Biol. 103, 468-481.

Weston, J. A. (1963), A radiographic analysis of the migration and localization of trunk neural crest cells in the chick. Dev. Biol. 6, 279-310.

Wilkinson, D. G., Bhatt, S., Cook M., Boncinelli, E., and Krumlauf, R. (1989). Segmental expression of Hox-2 homeobox-containing genes in the developing mouse hindbrain. Nature 341, 405-409.

(Accepted 15 April 1993) 